Research article

Open Access

\title{
Vitamin D receptor gene polymorphisms and haplotypes and postmenopausal breast cancer risk
}

\author{
Sascha Abbas ${ }^{1}$, Alexandra Nieters ${ }^{1}$, Jakob Linseisen ${ }^{1}$, Tracy Slanger ${ }^{1}$, Silke Kropp ${ }^{1}$, \\ Elke Jonny Mutschelknauss ${ }^{2}$, Dieter Flesch-Janys ${ }^{2}$ and Jenny Chang-Claude ${ }^{1}$
}

\author{
1Division of Cancer Epidemiology, German Cancer Research Center, Im Neuenheimer Feld, 69120 Heidelberg, Germany \\ 2Institute for Medical Biometrics and Epidemiology, University Clinic Hamburg-Eppendorf, Martinistr., 20246 Hamburg, Germany \\ Corresponding author: Jenny Chang-Claude, j.chang-claude@dkfz.de
}

Received: 21 Dec 2007 Revisions requested: 5 Feb 2008 Revisions received: 21 Feb 2008 Published: 17 Apr 2008

Breast Cancer Research 2008, 10:R31 (doi:10.1186/bcr1994)

This article is online at: http://breast-cancer-research.com/content/10/2/R31

(c) 2008 Abbas et al.; licensee BioMed Central Ltd.

This is an open access article distributed under the terms of the Creative Commons Attribution License (http://creativecommons.org/licenses/by/2.0), which permits unrestricted use, distribution, and reproduction in any medium, provided the original work is properly cited.

\begin{abstract}
Introduction Vitamin D receptor (VDR) genotypes may influence breast cancer risk by altering potential anticarcinogenic effects of vitamin $D$, but epidemiological studies have been inconsistent. Effect modification by serum 25-hydroxyvitamin D (25 [OH]D), the biomarker for vitamin D status in humans, has rarely been examined.

Methods We assessed the effects of two frequently analyzed polymorphisms (Fokl and Taql) and two potentially functional variants (VDR-5132 and $\mathrm{Cdx} 2)$ in the VDR gene, which thus far have not been analyzed with respect to breast cancer risk, on postmenopausal breast cancer risk in a population-based, casecontrol study including 1,408 patients (cases) and 2,612 control individuals (controls) matched for year of birth. Odds ratios (ORs) for breast cancer adjusted for potential confounders were calculated for genotypes and estimated haplotypes.

Results No differences in serum 25(OD)D concentrations by VDR genotype were observed. None of the analyzed polymorphisms was associated with overall risk for

postmenopausal breast cancer. However, the Taql polymorphism was associated with a significantly increased risk for oestrogen receptor positive tumours (OR $=1.18,95 \%$ confidence interval $[\mathrm{Cl}]=1.00$ to 1.38 , comparing $\mathrm{t}$ allele carriers with noncarriers) but not for oestrogen receptor negative tumours $(\mathrm{OR}=0.88,95 \% \mathrm{Cl}=0.69$ to $1.13 ; P$ for interaction $=0.04)$. Haplotype analysis revealed the haplotype FtCA (Fokl F, Taql t, VDR-5132 C, Cdx2 A), which contains the Taql t allele, to be associated with a significantly greater breast cancer risk as compared with the most frequent haplotype FTCG (OR $=1.43,95 \% \mathrm{Cl}=1.00$ to 2.05$)$. No significant interaction between VDR genotypes or haplotypes and 25(OH)D was observed.

Conclusion Our results support potential effects of VDR polymorphisms on postmenopausal breast cancer risk and possible differential effects of receptor status of the tumour. However, further studies focusing on the influence of polymorphisms and haplotypes on VDR functionality, activity and concentration are needed.
\end{abstract}

\section{Introduction}

In various observational studies vitamin D intake and serum concentrations of vitamin D metabolites have been associated with decreased risk for developing breast cancer [1-3]. Apart from the role that vitamin $D$ plays in maintaining calcium homeostasis, its antiproliferative effects - by influencing cell differentiation, cell growth and apoptosis - are well established [4$6]$.
Vitamin D from both diet and endogenous production is converted via two consecutive hydroxylation steps to 25-hydroxyvitamin $\mathrm{D}(25[\mathrm{OH}] \mathrm{D})$ and to 1,25 -dihydroxyvitamin $\mathrm{D}(1,25$ $\left.[\mathrm{OH}]_{2} \mathrm{D}\right)$. The biologically most active form of vitamin $\mathrm{D}$ is $1,25(\mathrm{OH})_{2} \mathrm{D}$, which mainly exerts its antiproliferative effects by binding to the vitamin $\mathrm{D}$ receptor (VDR) and acting in complex as a transcriptional factor for a variety of genes, including those involved in cell differentiation and cell growth [7]. The VDR is present in a variety of cell types, including malignant

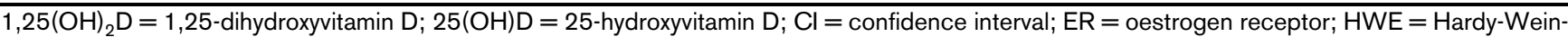
berg equilibrium; NHS = Nurses Health Study; OR = odds ratio; $\mathrm{PCR}=$ polymerase chain reaction; $\mathrm{PR}=$ progesterone receptor; $\mathrm{R}-\mathrm{N}-\mathrm{K}=\mathrm{R}$ heinNeckar-Karlsruhe; SNP = single nucleotide polymorphism; VDR = vitamin D receptor. 
and normal breast cells $[8,9]$. Various studies have assessed associations between various polymorphisms in the VDR gene and breast cancer risk, with inconsistent results. These polymorphisms include three frequently analyzed, highly linked single nucleotide polymorphisms (SNPs) Bsml, Apal and Taql at the $3^{\prime}$ end of the VDR gene. The t allele of the Taql SNP in exon 9 ( $r$ 731236, T/C, $C=t$ ), which leads to a silent codon change, has been found in different studies to be associated with a nonsignificantly increased breast cancer risk [10] and with a decreased risk for breast cancer [11], or there was no association at all [12-17].

Another promising functional polymorphism in the start codon at the $5^{\prime}$ promotor region of the VDR is the Fokl SNP (rs2228570/rs10735810, T/C, T = f). The f allele leads to a protein that is three amino acids longer and less effective $[18,19]$ and was associated with a statistically significant increased breast cancer risk in a case-control study nested within the Nurses Health Study (NHS) [20]. However, other studies did not find any association [11,14,21-23]. Furthermore, two potentially functional polymorphisms [24-26] located in two transcription factor binding sites within the VDR promoter region have been reported: VDR-5132 (rs1989969, $\mathrm{T} / \mathrm{C}$ ), which has been related to a potential elimination of a GATA-1 transcription factor binding site [25]; and Cdx2 (rs11568820, G/A), which leads to decreased transcriptional activity of the VDR promoter [26]. The Cdx2 polymorphism has been associated with risk for bone fracture $[27,28]$ and with risk for prostate cancer in $25(\mathrm{OH}) \mathrm{D}$ deficient men [29]; the VDR-5132 polymorphism has been related to risk for prostate cancer [25]. To our knowledge, neither polymorphism has yet been examined with respect to breast cancer risk.

The majority of studies assessing polymorphisms in the VDR gene and breast cancer risk have been very small and have often failed to account for known breast cancer risk factors and potential confounders in their analyses. Only one study has thus far assessed the association of breast cancer risk and VDR gene polymorphisms in relation to serum 25(OH)D [20], and it found no significant interactions. We recently reported an inverse association between serum 25(OH)D concentration and postmenopausal breast cancer risk in a large German case-control study [30]. We therefore assessed the association of Fokl, Taql, VDR-5132 and Cdx2 SNPs and their associated haplotypes with postmenopausal breast cancer risk and possible effect modification by serum $25(\mathrm{OH}) \mathrm{D}$ in this study population.

\section{Materials and methods Study population and data collection}

We conducted a large population-based, case-control study (MARIE [Mamma Carcinoma Risk factor Investigation] study) that was conducted in two regions in Germany: the city of Hamburg and the Rhein-Neckar-Karlsruhe (R-N-K) region. The study was approved by the ethics committees of both the Uni- versity of Heidelberg and the University of Hamburg, and it was conducted in accordance with the Declaration of Helsinki. All study participants gave informed consent. Patients (cases) were eligible if they had a histologically confirmed primary invasive or in situ breast cancer diagnosed between 1 January 2001 and 30 September 2005 in Hamburg and between 1 August 2002 and 31 July 2005 in the R-N-K region. Further inclusion criteria were age between 50 and 74 years and being a resident of one of the study regions. Cases were identified through frequent monitoring of hospital admissions, surgery schedules and pathology records. Clinical and pathological characteristics of the patients were abstracted from hospital and pathology records. Of the 5,970 eligible patients who could be contacted, 3,919 (65.6\%) participated and 2,051 (34.4\%) declined to participate or did not respond to letters of invitation.

Two control individuals (controls) per case were randomly selected from lists of residents provided by population registries and frequency matched by year of birth and study region to the cases. Of the 17,093 controls who met the inclusion criteria, 7,421 (43.4\%) participated, 7,521 (44.0\%) refused to participate and 2,151 (12.6\%) did not respond.

Using a standardized questionnaire all participants were interviewed by trained personnel to obtain information on sociodemographic factors and potential breast cancer risk factors.

Women who reported their last natural menstrual bleeding at least 12 months before the reference date (age at diagnosis and recruitment for cases and controls, respectively), a bilateral oophorectomy, or cessation of menses because of radiation or chemotherapy were defined as postmenopausal. Women older than 55 years with unclear menopausal status because of hysterectomy or hormone use were also considered postmenopausal (because the 90th percentile for age at menopause in women with natural menopause was 55 years). Premenopausal women and women under age 55 years with unclear menopausal status were excluded from the analysis. In total, 3,464 invasive or in situ breast cancer cases and 6,657 controls were classified as postmenopausal, of whom 1,559 cases and 3,008 controls were from the R-N-K region. Because of organizational aspects of sample handling, we included only participants from the R-N-K study region.

\section{Genotyping analysis}

Postmenopausal participants from the $\mathrm{R}-\mathrm{N}-\mathrm{K}$ region with DNA samples were included in this analysis, which included 1,408 $(90.3 \%)$ cases and $2,612(86.8 \%)$ controls.

Genomic DNA was extracted from blood samples using FlexiGene DNA Kit (Qiagen, Hilden, Germany), in accordance with the manufacturer's instruction. The Taql SNP was genotyped by PCR-restriction fragment length polymorphism. After PCR reaction, $5 \mu$ of the PCR product was digested with 1 unit of 
Taql restriction enzyme (New England Biolabs, Ipswich, MA, USA). The resultant fragments (242 base pairs [TT genotype], 131 and 111 base pairs [CC], and 111, 131 and 242 base pairs [TC]) were resolved on a $3.2 \%$ agarose gel. The Fokl, VDR-5132 and $\mathrm{Cdx} 2$ polymorphisms were genotyped using Pyrosequencing ${ }^{\text {TM }}$ technology (Biotage, Uppsala, Sweden) [31]. PCR mixtures contained 5 ng DNA, 1× Ready Mix PCR buffer (ABgene, Epsom, UK), $0.25 \cup$ Thermoprime DNA polymerase (ABgene), deoxynucleoside triphosphates (each at $167 \mu \mathrm{mol} / /$; PeqLab, Erlangen, Germany) and primers (3 pmol each), in a total reaction volume of $12 \mu \mathrm{l}$. Cycling conditions were identical for all SNPs, namely 40 cycles (except for Cdx2 [45 cycles]) of $94^{\circ} \mathrm{C}$ for 40 seconds, $57^{\circ} \mathrm{C}$ for 40 seconds and $72^{\circ} \mathrm{C}$ for 40 seconds.

The following primers $\left(5^{\prime} \rightarrow 3^{\prime}\right)$ were used: Taql: forward CTGCCGTTGAGTGTCTGTGT and reverse TCGGCTAGCTTCTGGATCAT; Fokl: AGGGCGAATCATGTATGAGG (PCR), GGTCAAAGTCTCCAGGGTCA (biotinylated) and TTGCTGTTCTTACAGGG (sequencing); VDR-5132: TGTCCTCATTTGGCCCCAGGA (PCR), ACCGGGTGGATGCAGAAAGG (bio) and GGGTGGTTGTCTA (seq); and Cdx2: CCCAAAAGGAAAGGAAGGAA (PCR), AAAGCAAACCAAGGGGTCTT (bio) and CCTGAGTAAACTAGGTCACA (seq). For quality control, 10\% of the samples were selected at random for repeated genotyping and concordance was $100 \%$. Samples with ambiguous results were repeated. The overall success rate for genotyping was above $99 \%$ for all four polymorphisms analyzed.

\section{Measurement of 25-hydroxyvitamin D}

For quantification of $25(\mathrm{OH}) \mathrm{D}$ in serum, we used the OCTEIA 25-hydroxyvitamin D enzyme immunoassay (IDS, Immunodiagnostic Systems Limited, Boldon, UK). We analyzed a subset of 1,391 postmenopausal cases and 1,365 randomly selected postmenopausal controls from the $\mathrm{R}-\mathrm{N}-\mathrm{K}$ region matched for year of birth (continuous) and time of blood collection (January to March, April to June, July to September, or October to December) in a single batch between November 2006 and January 2007. The coefficient of variation was $3.4 \%$ for intraassay determination and $7.6 \%$ for inter-assay determination. We measured 235 random samples (8.5\%) in duplicate. The average absolute deviation from the mean between two duplicates was $2.2 \%$.

\section{Data analysis}

Polymorphisms were tested for deviation from Hardy-Weinberg equilibrium (HWE) by comparing the observed and expected genotype frequencies using the $\chi^{2}$ test. To estimate linkage disequilibrium for each pair of polymorphisms, we calculated $r^{2}$.

Women were categorized both by genotype (homozygote minor allele, heterozygote, or homozygote major allele) and by carrier status (homozygote major allele or carrier of the minor allele) for the respective polymorphisms. We assessed the association of SNPs in the VDR gene and postmenopausal breast cancer risk by means of conditional logistic regression with stratification by year of birth (continuous) and additional stratification by time of blood collection (January to March, April to June, July to September, or October to December) in models assessing interaction with 25(OH)D. Homozygote major allele carriers were used as the reference category. We present odds ratios (ORs) and their corresponding 95\% confidence intervals $(\mathrm{Cls})$ under the assumption of a general and a dominant inheritance model. The following breast cancer risk factor variables were included in the multivariate model: age at menopause $(<47$ years, 47 to 51 years, 52 to 55 years, $\geq 56$ years, or unknown), body mass index $\left(<22.5 \mathrm{~kg} / \mathrm{m}^{2}, 22.5\right.$ to $<$ $25 \mathrm{~kg} / \mathrm{m}^{2}, 25$ to $<30 \mathrm{~kg} / \mathrm{m}^{2}$, or $\geq 30 \mathrm{~kg} / \mathrm{m}^{2}$ ), education level (low, middle, or high), first-degree family history of breast cancer (yes, no, or unknown), history of benign breast disease (yes or no), number of pregnancies (to week 28 or beyond; 0 , $1,2, \geq 3)$, age at menarche ( $<12$ years, 12 to 14 years, of $\geq 15$ years), breast feeding history (ever or never), total number of mammograms $(0,1$ to 4,5 to $9, \geq 10$, or unknown), smoking status (never, past, or current) and use of menopausal hormone therapy (never, past, or current).

Haplotype analysis was conducted using the $\mathrm{R}$ haplo.stats package [32]. Haplotypes and haplotype frequencies were estimated using the $\mathrm{R}$ function haplo.em. The association of common haplotypes with breast cancer risk was evaluated with the R function haplo.glm. Haplo.glm applies a haplotypetrait association test based on a general linear model framework using maximum likelihood estimates for haplotype effects, allowing for ambiguity of haplotype phase [33]. A logadditive risk model was assumed, in which haplotype specific regression coefficients represent the change in the log odds of disease for every additional copy of the haplotype compared with the homozygote reference haplotype. Because haplo.glm uses an unconditional approach, we adjusted for the same covariates as in the genotype analysis model but additionally adjusted for the matching variable year of birth and for time of blood collection in models assessing interaction with $25(\mathrm{OH}) \mathrm{D}$. The most common haplotype was set as the reference haplotype.

Statistical genotype-environment interaction was evaluated with the likelihood ratio test by including a cross-product term of the dichotomous VDR genotype variable (carriers versus noncarriers) and potential interaction variables of interest (continuous variable for $25[\mathrm{OH}] \mathrm{D}$ ) in the multivariate model. Statistical haplotype-environment interaction was evaluated using Wald statistics for the respective interaction term in haplo.glm, including interaction terms for all haplotypes simultaneously in the model.

Interaction of genotypes or haplotypes with oestrogen receptor (ER) or progesterone receptor (PR) status of the tumour 
was assessed by means of a case-only analysis. ER or PR status was used as the dependent variable (outcome) and potential interaction variables (genotypes and haplotypes) as independent variable in the logistic regression model. The Wald statistic for the respective independent variable was used to test for statistical interaction.

All tests were two-sided and considered to be statistically significant at $P \leq 0.05$. All calculations except the haplotype analysis were conducted using the statistical software SAS 9.1 (SAS Institute Inc., Cary, NC, USA).

\section{Results}

In comparison with controls, and consistent with established risk factors for breast cancer, cases were significantly older at menopause, were more likely to have a positive family history of breast cancer, more frequently had a history of benign breast disease, had lower parity, were younger at menarche, were less likely to have breastfed, had a greater number of previous mammograms, and more frequently used hormone therapy (Table 1).

Median 25(OH)D concentrations were $44.9 \mathrm{nmol} / \mathrm{l}$ and 51.5 $\mathrm{nmol} / \mathrm{l}$ for cases and controls, respectively. We did not observe significant differences in $25(\mathrm{OH}) \mathrm{D}$ concentrations by genotype in any of the four analyzed polymorphisms (Table 2).

The genotype distribution in the control group was in HWE for all analyzed polymorphisms $(P=0.30, P=0.31, P=0.39$ and $P=0.16$ for Fokl, Taql, VDR-5132 and $\mathrm{Cdx2}$, respectively). The observed allele frequencies in the controls were comparable to those reported in the dbSNP database for Caucasian populations (minor allele frequencies of $0.39,0.39,0.41$ and 0.19 for Fokl, Taql, VDR-5132 and Cdx2, respectively, in our study population). There was no evidence of linkage disequilibrium between any pair of the four analyzed polymorphism $\left(r^{2}\right.$ $<0.01)$.

We did not observe a significant association between genotypes of any of the four analyzed polymorphisms and risk for postmenopausal breast cancer (Table 3). In the subpopulation for whom there were data on serum $25(\mathrm{OH}) \mathrm{D}(1,391$ cases and 1,365 controls), we further examined whether the association between the VDR genotypes and breast cancer risk differed by serum 25(OH)D level. No departure from multiplicative interaction was observed when considering serum $25(\mathrm{OH}) \mathrm{D}$ level as a continuous variable $(P$ for interaction $=0.39,0.43,0.51$ and 0.61 for Fokl, Taql, VDR-5132 and $\mathrm{Cdx} 2$, respectively). Differential effects for the respective polymorphisms were also not found when serum 25(OH)D concentrations were dichotomized at $30 \mathrm{nmol} / \mathrm{l}$, which was defined as the cutt-off point for vitamin $D$ deficiency. Analyses stratified by season did not yield any further significant 25(OH)D-genotype interactions or differences in results between the winter months (October to March) and the sum- mer months (April to September). There was also no significant gene-environment interaction with family history of breast cancer, use of hormone therapy, or smoking status.

Because vitamin D possibly exerts its anticarcinogenic activities via the oestrogen pathway, we assessed possible differential effects by receptor status of the tumour. We observed a statistically significant interaction for the Taql polymorphism and ER status in a case-only model ( $P$ for interaction $=0.04$; Table 4). Comparing $t$ allele carriers with noncarriers, we found a statistically significantly increased OR of 1.18 (95\% $\mathrm{Cl}=1.00$ to 1.38 ) for ER-positive tumours, and an OR of 0.88 (95\% Cl $=0.69$ to 1.13 ) for ER-negative tumours. No statistically significant interaction was observed between the Taql polymorphism and PR status of the tumour, or between the Fokl, Cdx2, or VDR-5132 polymorphism and PR or ER status (Table 4). We also did not observe any differences in main or interaction effects by stage of disease, when we performed analysis stratified by local versus advanced tumours, according to TNM-staging of the tumour (Union Internationale Contre le Cancer classification).

We further estimated haplotypes by the expectation-maximization algorithm and included 15 haplotypes with a frequency above $1 \%$ in our analysis. The global test for an association of any haplotype and postmenopausal breast cancer risk was not significant $(P$ global $=0.72)$. However, under the log-additive model, the haplotype FtCA (Fokl F, Taql t, VDR-5132 C and $\mathrm{Cdx} 2 \mathrm{~A}$ ) was significantly associated with breast cancer risk compared with the most common haplotype FTCG (OR = $1.43,95 \% \mathrm{Cl}=1.00$ to 2.05 ; Table 5 ). Under the dominant model the OR was $1.53(95 \% \mathrm{Cl}=1.03$ to 2.30$)$ for those with at least one copy of the FtCA haplotype as compared with homozygote FTCG carriers. Power was inadequate using the recessive model. No statistical interaction was observed between any haplotypes and serum $25(\mathrm{OH}) \mathrm{D}$ concentration.

Analogous to the genotype analysis, we evaluated statistical interaction of haplotypes with receptor status of the tumour in a case-only analysis. We did not observe an interaction of any haplotype with ER status. For the haplotype FtCA with the significant main effect, the ORs were 1.34 (95\% Cl $=0.90$ to $2.01)$ and 1.67 (95\% Cl=0.94 to 2.99) for ER-positive and ER-negative tumours, respectively $(P$ for interaction $=0.64)$. A statistically significant interaction was found for the haplotype FtTA with PR status of the tumour ( $P$ for interaction $=0.03$ ), but haplotype frequency was very low $\left(f_{\mathrm{FtTA}}=0.016\right)$.

In a sensitivity analysis of haplotype associations, we additionally adjusted for $25(\mathrm{OH}) \mathrm{D}$ concentration in the subpopulation for whom there were data on 25(OH)D. ORs did not change substantially, but the OR for the risk haplotype FtCA was no longer significant because of lower numbers of cases and controls. 
Table 1

\begin{tabular}{|c|c|c|c|c|c|}
\hline \multirow[t]{2}{*}{ Characteristics } & \multicolumn{2}{|c|}{ Cases $\left(n^{a}=1,408\right)$} & \multicolumn{2}{|c|}{ Controls $\left(\mathrm{n}^{\mathrm{a}+}=2,612\right)$} & \multirow[t]{2}{*}{$P^{b}$} \\
\hline & $\mathrm{n}$ & $\%$ & $\mathrm{n}$ & $\%$ & \\
\hline Age at diagnosis/recruitment (years) & & & & & 0.87 \\
\hline 50 to 54 & 104 & 7.4 & 191 & 7.3 & \\
\hline 55 to 59 & 301 & 21.4 & 528 & 20.2 & \\
\hline 60 to 64 & 447 & 31.7 & 859 & 32.9 & \\
\hline 65 to 69 & 380 & 27.0 & 720 & 27.6 & \\
\hline$\geq 70$ & 176 & 12.5 & 314 & 12.0 & \\
\hline BMI $\left(\mathrm{kg} / \mathrm{m}^{2}\right)$ & & & & & 0.68 \\
\hline$<22.5$ & 554 & 39.4 & 1,043 & 39.9 & \\
\hline 22.5 to $<25$ & 473 & 33.6 & 829 & 31.8 & \\
\hline 25 to $<30$ & 323 & 22.9 & 624 & 23.9 & \\
\hline$\geq 30$ & 58 & 4.1 & 114 & 4.4 & \\
\hline Educational level & & & & & 0.07 \\
\hline Low & 912 & 64.8 & 1,761 & 67.4 & \\
\hline Middle & 305 & 21.6 & 559 & 21.4 & \\
\hline High & 191 & 13.6 & 292 & 11.2 & \\
\hline Age at menopause (years) & & & & & $<0.01$ \\
\hline$<47$ & 146 & 10.4 & 396 & 15.2 & \\
\hline 47 to 51 & 407 & 28.9 & 748 & 28.6 & \\
\hline 52 to 55 & 248 & 17.6 & 402 & 15.4 & \\
\hline$\geq 56$ & 63 & 4.5 & 115 & 4.4 & \\
\hline Unknown & 544 & 38.6 & 951 & 36.4 & \\
\hline First degree family history of breast cancer & & & & & $<0.01$ \\
\hline No & 1,113 & 79.1 & 2,164 & 82.8 & \\
\hline Yes & 234 & 16.6 & 329 & 12.6 & \\
\hline Unknown & 61 & 4.3 & 119 & 4.6 & \\
\hline Benign breast disease & & & & & $<0.01$ \\
\hline No & 860 & 61.3 & 1,833 & 70.5 & \\
\hline Yes & 544 & 38.7 & 766 & 29.5 & \\
\hline Number of pregnancies ( $\geq 28^{\text {th }}$ week) & & & & & $<0.01$ \\
\hline 0 & 200 & 14.2 & 294 & 11.3 & \\
\hline 1 & 383 & 27.2 & 635 & 24.3 & \\
\hline 2 & 518 & 36.8 & 1,031 & 39.5 & \\
\hline$\geq 3$ & 307 & 21.8 & 652 & 24.9 & \\
\hline Age at menarche (years) & & & & & 0.02 \\
\hline$<12$ & 125 & 8.9 & 221 & 8.5 & \\
\hline 12 to 14 & 950 & 67.5 & 1,658 & 63.7 & \\
\hline$\geq 15$ & 333 & 23.6 & 725 & 27.8 & \\
\hline
\end{tabular}


Table 1 (Continued)

Characteristics and risk factors for postmenopausal breast cancer in cases and matched controls in the study population

Ever breastfeeding

No

Yes

Number of mammograms in total

0

1 to 4

5 to 9

$\geq 10$

Unknown number

Use of hormone therapy

Never

Past

Current ( $\leq 6$ months)

Hormonal receptor status of the tumorc

ER-positive

ER-negative

PR-positive

PR-negative

Time of blood collectiond

January to March

April to June

July to September

October to December
555

853

195

598

343

254

18

528

293

572

994

308

848

453

317

292

402

380
$<0.01$

39.4

868

33.2

60.6

1,744

$<0.01$

$13.8 \quad 334$

1,370

12.8

42.5

599

52.5

24.4

288

22.9

18.0

21

11.0

1.3

0.8

37.9

1,113

43.1

21.0

672

26.0

41.1

798

30.9

aNumbers do not always add up to total numbers because of missing values. b ${ }^{2}$ test for differences between cases and controls. cData on estrogen receptor (ER) and progesterone receptor (PR) status was available for 1,302 and 1,301 invasive tumour cases (in situ tumours excluded), respectively. dData on serum 25 -hydroxyvitamin D status were available for 1,391 cases and 1,365 controls. BMI, body mass index.

\section{Discussion}

In this population-based, case-control study, none of the polymorphisms in the VDR gene were associated with postmenopausal breast cancer risk. However, there was effect modification by ER status of the tumour, so that $t$ allele car- riage of the Taql polymorphism was associated with significantly higher breast cancer risk as compared with noncarriage in ER-positive tumours only. Several studies reported no significant association between the Taql polymorphism and breast cancer risk [10,12-17], and only one study comparing

Table 2

Serum 25(OH)D concentrations in the control group by polymorphisms in the vitamin D receptor gene

\begin{tabular}{lllll}
\hline Polymorphism & Genotype & & & $P^{a}$ \\
\hline Taql & TT: $49.8(32.6-67.5)$ & Tt: $47.1(32.5-66.1)$ & tt: $48.1(32.7-69.8)$ & 0.52 \\
Fokl & FF: $49.2(33.0-66.9)$ & Ff: $48.2(32.4-67.4)$ & ff: $47.9(31.7-69.7)$ & 0.85 \\
VDR-5132 & CC: $49.1(32.9-66.9)$ & CT: $48.6(32.6-68.3)$ & TT: $47.7(31.6-66.9)$ & 0.78 \\
Cdx2 & GG: $48.5(32.5-67.4)$ & GA: $48.7(31.9-66.2)$ & AA: $50.7(35.0-68.6)$ & 0.56
\end{tabular}

Values are expressed as median serum 25-hydroxyvitamin $\mathrm{D}(25[\mathrm{OH}] \mathrm{D} ; 25$ th to 75 th percentile) in nmol/l. aWilcoxon rank-sum test for median differences by genotype. 
Table 3

\begin{tabular}{|c|c|c|c|c|c|c|c|c|c|}
\hline \multirow[t]{2}{*}{ Genotype } & \multicolumn{2}{|l|}{ Cases } & \multicolumn{2}{|c|}{ Controls } & \multicolumn{2}{|l|}{ Crude model ${ }^{\mathrm{a}}$} & \multicolumn{3}{|c|}{ Adjusted model ${ }^{b}$} \\
\hline & $\mathrm{n}$ & $\%$ & $n$ & $\%$ & OR $(95 \% \mathrm{Cl})$ & & OR $(95 \% \mathrm{Cl})$ & & $P^{c}$ \\
\hline Taql & 1,403 & & 2,609 & & & & & & 0.33 \\
\hline $\mathrm{TT}$ & 497 & 35.4 & 980 & 37.6 & 1 & & 1 & & \\
\hline $\mathrm{Tt}$ & 667 & 47.6 & 1,218 & 46.7 & 1.08 & $(0.94-1.25)$ & 1.08 & $(0.93-1.26)$ & \\
\hline $\mathrm{tt}$ & 239 & 17.0 & 411 & 15.7 & 1.15 & $(0.95-1.39)$ & 1.11 & $(0.91-1.36)$ & \\
\hline $\mathrm{Tt} / \mathrm{tt}$ & & & & & 1.10 & $(0.96-1.26)$ & 1.09 & $(0.95-1.26)$ & \\
\hline Fokl & 1,390 & & 2,596 & & & & & & 0.24 \\
\hline $\mathrm{FF}$ & 566 & 40.7 & 998 & 38.5 & 1 & & 1 & & \\
\hline $\mathrm{Ff}$ & 606 & 43.6 & 1,203 & 46.3 & 0.88 & $(0.77-1.02)$ & 0.89 & $(0.77-1.03)$ & \\
\hline $\mathrm{ff}$ & 218 & 15.7 & 395 & 15.2 & 0.98 & $(0.80-1.19)$ & 0.97 & $(0.79-1.19)$ & \\
\hline $\mathrm{Ff} / \mathrm{ff}$ & & & & & 0.91 & $(0.80-1.04)$ & 0.91 & $(0.79-1.05)$ & \\
\hline$V D R-5132$ & 1,400 & & 2,607 & & & & & & 0.92 \\
\hline $\mathrm{CC}$ & 488 & 34.9 & 892 & 34.2 & 1 & & 1 & & \\
\hline CT & 683 & 48.8 & 1,284 & 49.3 & 0.99 & $(0.85-1.14)$ & 1.00 & $(0.86-1.16)$ & \\
\hline TT & 229 & 16.3 & 431 & 16.5 & 0.99 & $(0.81-1.20)$ & 1.01 & $(0.83-1.24)$ & \\
\hline $\mathrm{CT} / \mathrm{TT}$ & & & & & 0.99 & $(0.86-1.13)$ & 1.00 & $(0.87-1.16)$ & \\
\hline Cdx2 & 1,406 & & 2,606 & & & & & & 0.22 \\
\hline GG & 888 & 63.1 & 1,701 & 65.3 & 1 & & 1 & & \\
\hline GA & 465 & 33.1 & 795 & 30.5 & 1.11 & $(0.97-1.28)$ & 1.08 & $(0.94-1.25)$ & \\
\hline AA & 53 & 3.8 & 110 & 4.2 & 0.94 & $(0.67-1.32)$ & 0.94 & $(0.66-1.33)$ & \\
\hline GA/AA & & & & & 1.09 & $(0.95-1.25)$ & 1.07 & $(0.93-1.23)$ & \\
\hline
\end{tabular}

aConditional logistic regression stratified by year of birth. ${ }^{b}$ Conditional logistic regression stratified by year of birth adjusted for age at menopause, first-degree family history of breast cancer, history of benign breast disease, number of pregnancies ( $\geq 28$ th week), age at menarche, breastfeeding history, total number of mammograms, use of hormone therapy, body mass index, education level and smoking status. ${ }^{c} \chi^{2}$ test for difference between cases and controls comparing the three genotypes for each polymorphism. Cl, confidence interval; OR, odds ratio.

allele frequencies found a significantly higher risk for the $\mathrm{T}$ allele [11]. However, these studies did not have sufficient power to differentiate by receptor status of the tumour. Our findings of an effect of Taql polymorphism only for ER-positive tumours suggest an oestrogen-mediated anticarcinogenic effect of vitamin D. Indeed, there are laboratory data that support the hypothesis that the anticarcinogenic effects of vitamin $D$ could be mediated via the oestrogen pathway by downregulation of the ER and thus attenuating estrogenic bioresponses such as cell growth [34,35]. In addition, a putative vitamin $D$ response element, serving as a binding site for the VDR-1,25(OH $)_{2}$ D-transcription factor complex, was found in the ER promoter [36].

The functionality of the Taql polymorphism is unclear. Although Taql is synonymous and in linkage disequilibrium with the two nonfunctional intron-located polymorphisms Bsml and Apal, linkage disequilibrium extends into the 3 ' regulatory region, which is known to be involved in regulation of VDR expression
[37]. Overall, functional studies - including studies on VDR mRNA expression - are inconsistent but tend to indicate a phenotype correlation with the frequently analyzed BAt haplotype (Bsml B Apal A and Taql t), including the Taql t allele [37]. However, data for 41 individuals in whom VDR mRNA and protein level were measured indicated significantly lower levels in both mRNA and protein in those with the tt genotype [38]. This is consistent with our finding of higher breast cancer risk for the Taql $t$ allele in ER-positive tumours, because less VDR mRNA and protein may result in less $1,25(\mathrm{OH})_{2} \mathrm{D}-\mathrm{VDR}$ complexes and therefore in less anticarcinogenic activity.

To our knowledge, this is the first study to examine $\mathrm{Cdx} 2$ and VDR-5132 polymorphisms and breast cancer risk. VDR-5132 leads to potential elimination of a GATA-1 transcription factor binding site [25], whereas $\mathrm{Cdx} 2$ leads to decreased transcriptional activity of the VDR promoter [26]. However, we found no association of Cdx2 or VDR-5132 SNPs with breast cancer risk in our study. 
Table 4

Odds ratios for postmenopausal breast cancer by genotypes in the vitamin D receptor gene according to ER and PR status of the tumour

\begin{tabular}{|c|c|c|c|c|c|c|c|c|c|}
\hline \multirow[t]{2}{*}{ Genotype } & \multirow[b]{2}{*}{$\begin{array}{l}\mathrm{n} \\
\text { (controls) }\end{array}$} & \multicolumn{2}{|c|}{ ER-positive tumours } & \multicolumn{2}{|c|}{ ER-negative tumours } & \multicolumn{2}{|c|}{ PR-positive tumours } & \multicolumn{2}{|c|}{ PR-negative tumours } \\
\hline & & $\begin{array}{l}\mathrm{n} \\
\text { (cases) }\end{array}$ & OR $(95 \% \mathrm{Cl})$ & $\begin{array}{l}\mathrm{n} \\
\text { (cases) }\end{array}$ & OR $(95 \% \mathrm{Cl})$ & $\begin{array}{l}\mathrm{n} \\
\text { (cases) }\end{array}$ & OR $(95 \% \mathrm{Cl})$ & $\begin{array}{l}\mathrm{n} \\
\text { (cases) }\end{array}$ & OR $(95 \% \mathrm{Cl})$ \\
\hline \multicolumn{10}{|l|}{ Taql } \\
\hline TT & 980 & 337 & 1 & 121 & 1 & 297 & 1 & 159 & 1 \\
\hline$T t / t t$ & 1,629 & 653 & $1.18(1.00-1.38)$ & 186 & $0.88(0.69-1.13)$ & 547 & $1.10(0.93-1.30)$ & 293 & $1.11(0.89-1.37)$ \\
\hline \multicolumn{10}{|l|}{ Fokl } \\
\hline $\mathrm{FF}$ & 998 & 394 & 1 & 127 & 1 & 331 & 1 & 190 & 1 \\
\hline $\mathrm{Ff} / \mathrm{ff}$ & 1,598 & 586 & $0.95(0.81-1.10)$ & 177 & $0.86(0.67-1.10)$ & 505 & $0.96(0.82-1.14)$ & 257 & $0.84(0.68-1.03)$ \\
\hline \multicolumn{10}{|l|}{ VDR-5132 } \\
\hline $\mathrm{CC}$ & 892 & 347 & 1 & 113 & 1 & 298 & 1 & 162 & 1 \\
\hline $\mathrm{CT} / \mathrm{TT}$ & 1,715 & 640 & $0.99(0.84-1.16)$ & 194 & $0.92(0.71-1.18)$ & 543 & $0.97(0.82-1.15)$ & 290 & $0.97(0.78-1.20)$ \\
\hline \multicolumn{10}{|l|}{$\mathrm{Cdx} 2$} \\
\hline GG & 1,701 & 641 & 1 & 190 & 1 & 546 & 1 & 283 & 1 \\
\hline GA/AA & 905 & 351 & $1.01(0.86-1.17)$ & 118 & $1.14(0.88-1.46)$ & 301 & $1.01(0.86-1.20)$ & 169 & $1.11(0.90-1.38)$ \\
\hline
\end{tabular}

We conducted a conditional logistic regression stratified by year of birth adjusted for age at menopause, first-degree family history of breast cancer, history of benign breast disease, number of pregnancies ( $\geq 28$ th week), age at menarche, breastfeeding history, total number of mammograms, use of hormone therapy, body mass index, education level and smoking status. Data on oestrogen receptor (ER) and progesterone receptor (PR) status was available for 1,302 and 1,301 cases, respectively.

Our results for the Fokl polymorphism do not support the findings of a large case-control study nested in the NHS reporting a significantly increased risk with the ff versus the FF genotype [20]. Although this polymorphism is known to be functional $[18,39]$, numerous other studies, including the present one, were unable to confirm the finding from the NHS $[11,14,21$ 23].

In a haplotype analysis, we found the haplotype FtCA (Fokl F, Taql t, VDR-5132 C, Cdx2 A) to be associated with a significantly greater breast cancer risk as compared with the most frequent haplotype (FTCG). The reason for this finding is unclear. The FtCA haplotype (versus the FTCG reference haplotype) contains the transcriptionally more active $\mathrm{Cdx} 2 \mathrm{~A}$ allele [26], which is expected to be associated with a decreased risk for breast cancer. On the other hand, in accordance with the observed increased risk associated with Taql $t$ allele carriage in ER-positive tumours, the $t$ allele is also present in the FtCA risk haplotype. Nevertheless, because of the multiple comparisons in our analysis, we cannot exclude the possibility that the observed significant associations may be chance findings.

We recently reported an inverse association between serum 25(OH)D concentration and postmenopausal breast cancer risk [30] and therefore were interested in assessing possible interaction between 25(OH)D status and genotype. Geneenvironment interactions may explain inconsistencies in associations between polymorphisms and breast cancer risk in dif- ferent studies. However, we did not find evidence for interactions of VDR polymorphisms with $25(\mathrm{OH}) \mathrm{D}$ (the observed inverse association of $25[\mathrm{OH}] \mathrm{D}$ and breast cancer risk was not modified by genotype). Our results corroborate the findings in the NHS of an absence of interaction between the Fokl SNP and 25(OH)D [20]. Functional variants of the VDR might affect 25(OH)D concentration, because the VDR is possibly involved in negative feedback regulation of $1,25(\mathrm{OH})_{2} \mathrm{D}$ synthesis mediated by the $1 \alpha$-hydroxylase, which is the enzyme that converts $25(\mathrm{OH}) \mathrm{D}$ to active $1,25(\mathrm{OH})_{2} \mathrm{D}$ [40]. However, 25(OH)D levels did not vary by VDR genotype in our population, which is consistent with results on the relation between Fokl and Taql polymorphisms and vitamin D status in previous smaller studies $[38,41]$.

Strengths of our study are the large sample size, the adjustment for all potential breast cancer risk factors, the evaluation of interactions with serum 25(OH)D, and the restriction to postmenopausal women, because various studies so far have not differentiated between premenopausal and postmenopausal women. Genotyping errors can almost completely be excluded, because $10 \%$ of the samples were genotyped in duplicate and concordance was $100 \%$. In addition, all analyzed polymorphisms were in HWE and allele frequencies were comparable to those reported in the dbSNP database for Caucasian populations. 
Table 5

Odds ratios for postmenopausal breast cancer by haplotypes in the vitamin D receptorgene under the log-additive model

\begin{tabular}{|c|c|c|c|c|c|c|}
\hline \multirow[t]{2}{*}{ Haplotype $^{a}$} & \multicolumn{2}{|c|}{ Haplotype frequencies (\%) } & \multicolumn{4}{|c|}{ OR $(95 \% \mathrm{Cl})$} \\
\hline & Cases $(n=1,408)$ & Controls $(n=2,612)$ & Crude & del $l^{b}$ & Adjus & modelc \\
\hline FTCG & 0.178 & 0.183 & 1 & & 1 & \\
\hline FTCA & 0.036 & 0.049 & 0.76 & $(0.51-1.15)$ & 0.81 & $(0.53-1.23)$ \\
\hline FTTG & 0.124 & 0.116 & 1.12 & $(0.87-1.43)$ & 1.09 & $(0.84-1.40)$ \\
\hline FTTA & 0.025 & 0.025 & 1.10 & $(0.69-1.77)$ & 1.16 & $(0.71-1.88)$ \\
\hline $\mathrm{FtCG}$ & 0.117 & 0.113 & 1.07 & $(0.83-1.38)$ & 1.06 & $(0.82-1.39)$ \\
\hline $\mathrm{FtCA}$ & 0.052 & 0.035 & 1.50 & $(1.07-2.12)$ & 1.43 & $(1.00-2.05)$ \\
\hline FtTG & 0.076 & 0.079 & 0.98 & $(0.76-1.27)$ & 1.04 & $(0.80-1.36)$ \\
\hline FtTA & 0.016 & 0.015 & 1.05 & $(0.59-1.87)$ & 0.98 & $(0.54-1.79)$ \\
\hline fTCG & 0.109 & 0.117 & 0.97 & $(0.75-1.24)$ & 0.97 & $(0.75-1.26)$ \\
\hline fTCA & 0.028 & 0.023 & 1.19 & $(0.72-1.96)$ & 1.17 & $(0.70-1.95)$ \\
\hline fTTG & 0.080 & 0.083 & 0.98 & $(0.75-1.26)$ & 1.04 & $(0.80-1.35)$ \\
\hline fTTA & 0.011 & 0.011 & 1.07 & $(0.48-2.37)$ & 0.93 & $(0.41-2.09)$ \\
\hline $\mathrm{ftCG}$ & 0.048 & 0.041 & 1.19 & $(0.84-1.69)$ & 1.19 & $(0.82-1.72)$ \\
\hline $\mathrm{ftCA}$ & 0.024 & 0.027 & 0.94 & $(0.57-1.55)$ & 0.95 & $(0.56-1.64)$ \\
\hline $\mathrm{ftTG}$ & 0.065 & 0.072 & 0.94 & $(0.71-1.25)$ & 0.94 & $(0.70-1.27)$ \\
\hline
\end{tabular}

aFokl, Tagl, VDR-5132, Cdx2 (with $>1 \%$ frequency in the study population). bUnconditional haplotype analysis adjusted for matching factor year of birth. cUnconditional haplotype analysis adjusted for year of birth, age at menopause, first-degree family history of breast cancer, history of benign breast disease, number of pregnancies ( $\geq 28$ th week), age at menarche, breastfeeding history, total number of mammograms, use of hormone therapy, body mass index, education level and smoking status. $\mathrm{Cl}$, confidence interval; OR, odds ratio.

We selected mainly functional variants in order to assess their effects on breast cancer risk. However, observed associations may have arisen from other unknown functional variants in linkage with the analyzed polymorphisms in our study. In contrast, the haplotype analysis was exploratory because functionality of the analyzed haplotypes is unknown. Therefore, further studies with respect to functionality of haplotypes are necessary.

Limitations due to the retrospective case-control design are of less importance when assessing genetic variations, and thus selection bias is unlikely to have biased our results. However, when interpretating the null interactions with serum $25(\mathrm{OH}) \mathrm{D}$, the low response rate in the population controls and measurement of $25(\mathrm{OH}) \mathrm{D}$ after diagnosis in the cases may be of concern. Information on $25(\mathrm{OH}) \mathrm{D}$ status, diet, or vitamin $\mathrm{D}$ related variables such as outdoor activity in nonparticipants was not available. A cancer diagnosis may change dietary or behavioural habits, which may influence $25(\mathrm{OH}) \mathrm{D}$ concentrations. Modification of dietary habits after a cancer diagnosis appears to be limited [42], but cases might have had less opportunity for outdoor activities (sun exposure) after diagnosis, leading to potential differences in $25(\mathrm{OH}) \mathrm{D}$ status between cases and controls. The median difference between time of diagnosis and time of blood collection in the cases was, however, fairly low (median [25th to 75th percentile] $=80$ [14 to 260] days). The null results for the interaction between genotypes/haplo- types and $25(\mathrm{OH}) \mathrm{D}$ might also have been biased by potential influence of chemotherapy on $25(\mathrm{OH}) \mathrm{D}$ concentration. However, a notable change in $25(\mathrm{OH}) \mathrm{D}$ concentration after chemotherapeutic treatment was not observed in two studies $[43,44]$.

Our findings are not representative for non-Caucasian populations because women in our population are primarily Caucasian and allele frequencies vary widely among populations of different ethnic origin.

\section{Conclusion}

None of the analyzed polymorphisms was associated with risk for breast cancer overall. However, the t allele of the Taql polymorphism was associated with a significantly increased breast cancer risk in ER-positive tumours only. In a haplotype analysis the haplotype FtCA (Fokl F, Taql t, VDR-5132 C, Cdx2 A) was associated with a significantly higher breast cancer risk as compared with the most frequent haplotype (FTCG). No significant interaction between VDR SNPs or haplotypes and serum 25(OH)D was found. Our results support potential effects of VDR polymorphisms on postmenopausal breast cancer risk. Further epidemiological studies assessing the association of vitamin D and breast cancer risk should take the receptor status of the tumour and other gene variants of oestrogen metabolism into account. In addition, more studies 
on certain polymorphisms and haplotypes in the VDR, especially functional studies with respect to impact on VDR activity and concentration, are needed.

\section{Competing interests}

The authors declare that they have no competing interests.

\section{Authors' contributions}

SA performed the laboratory analysis and data analysis, and drafted the manuscript. AN contributed to the genotyping analysis and revised the manuscript. JL gave advice on the data analysis and contributed to writing of the manuscript. TS, SK and EJM reviewed the manuscript and participated in designing the study. DF and JC were responsible for the study design, gave advice on the data analysis and revised the manuscript. All authors read and approved the final manuscript.

\section{Acknowledgements}

We are grateful to all participants for their help and patience, to all hospitals that recruited patients for inclusion in this study, and to the collaborating pathologists who provided detailed histological diagnoses and immunohistochemical examination findings for tumour samples. We also thank M Auer, S Behrens, R Birr, W Busch, B Ehret, U Eilber, B Kaspereit, N Knese, S Patommel and K Smit for valuable technical assistance.

This study was supported by the Deutsche Krebshilfe e V, grant number 70-2892-BR I. S Abbas has a scholarship from the Deutsche Forschungsgemeinschaft, Graduiertenkolleg 793.

\section{References}

1. Bertone-Johnson ER, Chen WY, Holick MF, Hollis BW, Colditz GA, Willett WC, Hankinson SE: Plasma 25-hydroxyvitamin d and 1,25-dihydroxyvitamin $D$ and risk of breast cancer. Cancer Epidemiol Biomarkers Prev 2005, 14:1991-1997.

2. Colston KW, Lowe LC, Mansi JL, Campbell MJ: Vitamin D status and breast cancer risk. Anticancer Res 2006, 26:2573-2580.

3. Shin MH, Holmes MD, Hankinson SE, Wu K, Colditz GA, Willett WC: Intake of dairy products, calcium, and vitamin $\mathrm{d}$ and risk of breast cancer. J Natl Cancer Inst 2002, 94:1301-1311.

4. Bouillon R, Eelen G, Verlinden L, Mathieu C, Carmeliet G, Verstuyf A: Vitamin D and cancer. J Steroid Biochem Mol Biol 2006, 102:156-162

5. Colston KW, Hansen CM: Mechanisms implicated in the growth regulatory effects of vitamin $\mathrm{D}$ in breast cancer. EndocrineRelated Cancer 2002, 9:45-59.

6. Christakos S, Dhawan P, Liu Y, Peng X, Porta A: New insights into the mechanisms of vitamin D action. J Cell Biochem 2003, 88:695-705.

7. Hansen CM, Binderup L, Hamberg KJ, Carlberg C: Vitamin D and cancer: effects of $1,25(\mathrm{OH})_{2} D_{3}$ and its analogs on growth control and tumorigenesis. Front Biosci 2001, 6:D820-D848.

8. Colston K, Colston MJ, Fieldsteel AH, Feldman D: 1,25-dihydroxyvitamin $D_{3}$ receptors in human epithelial cancer cell lines. Cancer Res 1982, 42:856-859.

9. Townsend K, Banwell CM, Guy M, Colston KW, Mansi JL, Stewart PM, Campbell MJ, Hewison M: Autocrine metabolism of vitamin $D$ in normal and malignant breast tissue. Clin Cancer Res 2005, 11:3579-3586.

10. Sillanpaa $P$, Hirvonen $A$, Kataja $V$, Eskelinen $M$, Kosma VM, Uusitupa $\mathrm{M}$, Vainio $\mathrm{H}$, Mitrunen K: Vitamin D receptor gene polymorphism as an important modifier of positive family history related breast cancer risk. Pharmacogenetics 2004, 14:239-245

11. Curran JE, Vaughan T, Lea RA, Weinstein SR, Morrison NA, Griffiths LR: Association of A vitamin D receptor polymorphism with sporadic breast cancer development. Int J Cancer 1999, 83:723-726.

12. Buyru N, Tezol A, Yosunkaya-Fenerci E, Dalay N: Vitamin D receptor gene polymorphisms in breast cancer. Exp Mol Med 2003, 35:550-555.

13. Hou MF, Tien YC, Lin GT, Chen CJ, Liu CS, Lin SY, Huang TJ: Association of vitamin $D$ receptor gene polymorphism with sporadic breast cancer in Taiwanese patients. Breast Cancer Res Treat 2002, 74:1-7.

14. McCullough ML, Stevens VL, Diver WR, Feigelson HS, Rodriguez C, Bostick RM, Thun MJ, Calle EE: Vitamin D pathway gene polymorphisms, diet, and risk of postmenopausal breast cancer: a nested case-control study. Breast Cancer Res 2007, 9:R9.

15. Lundin AC, Soderkvist $P$, Eriksson $B$, Bergman-Jungestrom $M$, Wingren S: Association of breast cancer progression with a vitamin D receptor gene polymorphism. South-East Sweden Breast Cancer Group. Cancer Res 1999, 59:2332-2334.

16. Newcomb PA, Kim H, Trentham-Dietz A, Farin F, Hunter D, Egan $\mathrm{KM}$ : Vitamin $\mathrm{D}$ receptor polymorphism and breast cancer risk. Cancer Epidemiol Biomarkers Prev 2002, 11:1503-1504.

17. Dunning AM, McBride S, Gregory J, Durocher F, Foster NA, Healey CS, Smith N, Pharoah PD, Luben RN, Easton DF, Ponder BA: No association between androgen or vitamin $D$ receptor gene polymorphisms and risk of breast cancer. Carcinogenesis 1999, 20:2131-2135.

18. Arai $H$, Miyamoto $K$, Taketani $Y$, Yamamoto $H$, lemori $Y$, Morita $K$, Tonai T, Nishisho T, Mori S, Takeda E: A vitamin D receptor gene polymorphism in the translation initiation codon: effect on protein activity and relation to bone mineral density in Japanese women. J Bone Miner Res 1997, 12:915-921.

19. Colin EM, Weel AE, Uitterlinden AG, Buurman CJ, Birkenhäger JC, Pols $H A$, van Leeuwen JP. Consequences of vitamin $D$ receptor gene polymorphisms for growth inhibition of cultured human peripheral blood mononuclear cells by 1,25 -dihydroxyvitamin D. $_{3}$ Clin Endocrinol (Oxf) 2000, 52:211-216.

20. Chen WY, Bertone-Johnson ER, Hunter DJ, Willett WC, Hankinson SE: Associations between polymorphisms in the vitamin D receptor and breast cancer risk. Cancer Epidemiol Biomarkers Prev 2005, 14:2335-2339.

21. Guy M, Lowe LC, Bretherton-Watt D, Mansi JL, Peckitt C, Bliss J, Wilson RG, Thomas V, Colston KW: Vitamin D receptor gene polymorphisms and breast cancer risk. Clin Cancer Res 2004, 10:5472-5481.

22. Bretherton-Watt D, Given-Wilson R, Mansi JL, Thomas V, Carter N, Colston KW: Vitamin D receptor gene polymorphisms are associated with breast cancer risk in a UK Caucasian population. Br J Cancer 2001, 85:171-175.

23. Ingles SA, Garcia DG, Wang W, Nieters A, Henderson BE, Kolonel LN, Haile RW, Coetzee GA: Vitamin D receptor genotype and breast cancer in Latinas (United States). Cancer Causes Control 2000, 11:25-30

24. Yamamoto $H$, Miyamoto $K$, Li B, Taketani $Y$, Kitano $M$, Inoue $Y$, Morita K, Pike JW, Takeda E: The caudal-related homeodomain protein $\mathrm{Cdx}-2$ regulates vitamin $\mathrm{D}$ receptor gene expression in the small intestine. J Bone Miner Res 1999, 14:240-247.

25. Kidd LC, Paltoo DN, Wang S, Chen W, Akereyeni F, Isaacs W, Ahaghotu C, Kittles R: Sequence variation within the 5 ' regulatory regions of the vitamin $D$ binding protein and receptor genes and prostate cancer risk. Prostate 2005, 64:272-282.

26. Arai $\mathrm{H}$, Miyamoto KI, Yoshida M, Yamamoto $\mathrm{H}$, Taketani $\mathrm{Y}$, Morita K, Kubota M, Yoshida S, Ikeda M, Watabe F, Kanemasa Y, Takeda $\mathrm{E}:$ The polymorphism in the caudal-related homeodomain protein $\mathrm{Cdx}-2$ binding element in the human vitamin $\mathrm{D}$ receptor gene. J Bone Miner Res 2001, 16:1256-1264.

27. Fang $Y$, van Meurs JB, Bergink AP, Hofman $A$, van Duijn $C M$, van Leeuwen JP, Pols HA, Uitterlinden AG: Cdx-2 polymorphism in the promoter region of the human vitamin $D$ receptor gene determines susceptibility to fracture in the elderly. $J$ Bone Miner Res 2003, 18:1632-1641.

28. Uitterlinden AG, Ralston $\mathrm{SH}$, Brandi ML, Carey AH, Grinberg D, Langdahl BL, Lips $\mathrm{P}$, Lorenc R, Obermayer-Pietsch B, Reeve J, Reid DM, Amedei A, Bassiti A, Bustamante M, Husted LB, DiezPerez A, Dobnig H, Dunning AM, Enjuanes A, Fahrleitner-Pammer A, Fang Y, Karczmarewicz E, Kruk M, van Leeuwen JP, Mavilia C, van Meurs JB, Mangion J, McGuigan FE, Pols HA, Renner W, et al.: The association between common vitamin $D$ receptor gene 
variations and osteoporosis: a participant-level meta-analysis. Ann Intern Med 2006, 145:255-264.

29. Mikhak B, Hunter DJ, Spiegelman D, Platz EA, Hollis BW, Giovannucci $E$ : Vitamin $D$ receptor (VDR) gene polymorphisms and haplotypes, interactions with plasma 25-hydroxyvitamin D and 1,25-dihydroxyvitamin D, and prostate cancer risk. Prostate 2007, 67:911-923.

30. Abbas S, Linseisen J, Slanger T, Kropp S, Mutschelknauss EJ, Flesch-Janys D, Chang-Claude J: Serum 25-hydroxyvitamin D and risk of post-menopausal breast cancer: results of a large casecontrol study. Carcinogenesis 2008, 29:93-99.

31. Fakhrai-Rad H, Pourmand N, Ronaghi M: Pyrosequencing: an accurate detection platform for single nucleotide polymorphisms. Hum Mutat 2002, 19:479-485.

32. The R Project for Statistical Computing [http://www.rproject.org]

33. Lake SL, Lyon H, Tantisira K, Silverman EK, Weiss ST, Laird NM, Schaid DJ: Estimation and tests of haplotype-environment interaction when linkage phase is ambiguous. Hum Hered 2003, 55:56-65.

34. James SY, Mackay AG, Binderup L, Colston KW: Effects of a new synthetic vitamin $D$ analogue, EB on the oestrogen-responsive growth of human breast cancer cells. J Endocrinol 1089, 141:555-563.

35. Swami S, Krishnan AV, Feldman D: 1alpha,25-dihydroxyvitamin $D_{3}$ down-regulates estrogen receptor abundance and suppresses estrogen actions in MCF-7 human breast cancer cells. Clin Cancer Res 2000, 6:3371-3379.

36. Stoica A, Saceda M, Fakhro A, Solomon HB, Fenster BD, Martin MB: Regulation of estrogen receptor-alpha gene expression by 1,25 -dihydroxyvitamin D in MCF-7 cells. $J$ Cell Biochem 1999, 75:640-651.

37. Uitterlinden AG, Fang $Y$, van Meurs JB, Pols HA, Van Leeuwen JP: Genetics and biology of vitamin D receptor polymorphisms. Gene 2004, 338:143-156.

38. Ogunkolade BW, Boucher BJ, Prahl JM, Bustin SA, Burrin JM, Noonan K, North BV, Mannan N, McDermott MF, DeLuca HF, Hitman GA: Vitamin D receptor (VDR) mRNA and VDR protein levels in relation to vitamin $D$ status, insulin secretory capacity, and VDR genotype in Bangladeshi Asians. Diabetes 2002, 51:2294-2300.

39. Whitfield GK, Remus LS, Jurutka PW, Zitzer H, Oza AK, Dang HT, Haussler CA, Galligan MA, Thatcher ML, Encinas Dominguez C, Haussler MR: Functionally relevant polymorphisms in the human nuclear vitamin D receptor gene. Mol Cell Endocrinol 2001, 177:145-159.

40. Takeyama K, Kitanaka S, Sato T, Kobori M, Yanagisawa J, Kato S: 25-Hydroxyvitamin D3 1alpha-hydroxylase and vitamin D synthesis. Science 1997, 277:1827-1830.

41. Vupputuri MR, Goswami R, Gupta N, Ray D, Tandon N, Kumar N: Prevalence and functional significance of 25-hydroxyvitamin $D$ deficiency and vitamin $D$ receptor gene polymorphisms in Asian Indians. Am J Clin Nutr 2006, 83:1411-1419.

42. Zheng W, Dai $Q$, Custer $\sqcup$, Shu XO, Wen WO, Jin F, Franke AA: Urinary excretion of isoflavonoids and the risk of breast cancer. Cancer Epidemiol Biomarkers Prev 1999, 8:35-40.

43. Kailajarvi ME, Salminen EK, Paija OM, Virtanent AM, Leino AE, Irjala KA: Serum bone markers in breast cancer patients during 5-fluorouracil, epirubicin and cyclophosphamide (FEC) therapy. Anticancer Res 2004, 24:1271-1274.

44. Gao Y, Shimizu M, Yamada S, Ozaki Y, Aso T: The effects of chemotherapy including cisplatin on vitamin D metabolism. Endocr J 1993, 40:737-742. 